\title{
Hydrocarbons in Soil from Basra Oil-Rich Governorate
}

\author{
${ }^{1}$ Ali Abdul Al-Zahra Douabul, ${ }^{2}$ Wisam Abdul Ameer Farid, \\ ${ }^{1}$ Hamid Talib Al-Saad and ${ }^{3}$ Sama Sameer AlMaarofi \\ ${ }^{1}$ Department of Marine Environmental Chemistry, Marine Science Center, University of Basra, Iraq \\ ${ }^{2}$ College of Health and Medical Technology, Faculty of Medicen, University of Basra, Basra, Iraq \\ ${ }^{3}$ Department of Biology, Faculty of Science, University of Waterloo, Waterloo-Ontario, Canada
}

Received 2012-08-15, Revised 2012-09-15; Accepted 2012-09-18

\begin{abstract}
Basra is a rich-oil region; its soil is expected to be contaminated with petroleum hydrocarbons. However, there is no previous study that has estimated the levels of hydrocarbons in Basra soil. After 2003 numerous operations by several international oil companies are underway. Therefore, the determination of background levels of petroleum hydrocarbons is a priority from environmental point of view. The present study was carried out to determine the distribution and seasonal variations of petroleum hydrocarbons in ten sites in Basra Governorate, southern Iraq. The results obtained in this study can service as baseline for future environmental impact assessment of oil operations.
\end{abstract}

Keywords: Basra, Oil Pollution, Petroleum Hydrocarbons, PAHs, Impact Assessment

\section{INTRODUCTION}

Hydrocarbons are considered as an important class of environmental pollutants especially in areas where oil is found. This may be due to anthropogenic activities such as spillage, leakages and handling of crude oils (FarrellJones, 2003; Butler et al., 1984). Soils can also retain relatively low amounts of hydrocarbons from natural sources "biogenic" such as higher plants. The concentrations of hydrocarbons in soil are strongly related to the sorbed organic matter (Zhang et al., 2012; Whittaker et al., 1999), similarly the present study has confirmed. On the other hand, hydrocarbons may be removed from soil via several processes such as volatilization, photo-oxidation, chemical reactions, leaching and biodegradation (Grimalt and Olive, 1993). Pending on environmental conditions, some of these processes may take very long time and thus portion of these compounds will remain in soil and become more resistant (Barakat et al., 2001). Increasing hydrocarbons levels in the environment can cause pollution to the natural resources (Buddhadasa et al., 2002). On the other hand, poly-nuclear aromatic hydrocarbons considered major carcinogenic component that can cause serious health problems (Apitz and Meyers-Schulte, 1996; API, 2001; Askari and Pollard, 2005). High levels of hydrocarbons are expected to be encountered in several locations within Basra Governorate. In addition to the numerous oil operations, there are additional sources of hydrocarbons to this region such as industries, power generation and gas productions. Inadequate waste management suggests high levels of hydrocarbons residues in Basra soil, especially within the industrial zone. The main objectives of this study are to determine the baseline hydrocarbon concentrations in Basra soil and point their main sources in an attempt to correlate their impact upon surrounding areas.

\section{MATERIALS AND METHODS}

Ten sampling locations were selected across Basra Governorate based upon vicinity to oil operations, industrial sites and urban areas. Thus, Basra station is mainly affected by electrical generating plants and units. Al-Rumayllah and Al-Seeba areas host the largest oil refineries. Fao port is station suspected to be heavily influenced by oil exportation. The rest stations are mainly urban areas

\footnotetext{
Corresponding Author: Ali Abdul Al-Zahra Douabul, Department of Marine Environmental Chemistry, Marine Science Center, University of Basra, Iraq
} 
including: Al-Qurna, Garmett Ali, Al-Shiabah, Abu Kaseeb, Saffwan and Um Qasir. Replicate soil samples were collected using hand auger from each station during 2009 to account for winter and summer season.

Samples were wrapped in aluminum foil and placed in sterilized containers and kept in the laboratory deep freeze. The samples then were freezedried, grounded finely by agate mortar and sieved through a $62 \mu$ stainless steel sieve. Hydrocarbons were extracted from soil followed the procedure described by Grimalt and Olive (1993) and Tuteja et al. (2011). The extracts were divided into two portions. The first portion was used to determine total petroleum hydrocarbons using a Shimadzu RF-540 spectroflurometer. The extract volume was reduced using a rotary evaporator to $10 \mathrm{~mL}$ and then sabonified for $2 \mathrm{~h}$ with a solution of $4 \mathrm{~N} \mathrm{KOH}$ in $1: 1$ methanol: Benzene and then dried by anhydrous $\mathrm{Na}_{2} \mathrm{SO}_{4}$ and concentrated by a stream of nitrogen. Petroleum hydrocarbons were quantified by measuring the emission intensity at $360 \mathrm{~nm}$, with excitation set at $310 \mathrm{~nm}$ and monochromatic slits of $10 \mathrm{~nm}$. The second portion of the extract was used to determine the aliphatic (n-alkanes) and aromatic hydrocarbons using a Perkin-Elmer sigma 300 gas chromatograph. Prior to GC analysis the extracts were cleaned by passing them through column filled with $8 \mathrm{~g}$ of $5 \%$ deactivated alumina (100-200 mesh) on the top and silica (100-200 mesh) in the bottom. The samples then were eluted by $50 \mathrm{~mL}$-hexane (aliphatic fraction) followed by $50 \mathrm{~mL}$ of benzene (aromatic fraction). Both fractions were reduced to suitable volume and subjected to GC analysis. Helium gas was used as a carrier gas with a linear velocity of $1.5 \mathrm{~mL} \mathrm{~min}^{-1}$. The operating temperatures for detector and injector were $350^{\circ} \mathrm{C}$ and $320^{\circ} \mathrm{C}$, respectively. The silica capillary column was operated under initial, final and rate temperatures that programmed as follows: Initial temperatures were $60^{\circ} \mathrm{C}$ for aliphatic fraction for 4 min and $70^{\circ} \mathrm{C}$ for aromatic fraction for $0 \mathrm{~min}$, while final temperatures were $280^{\circ} \mathrm{C}$ for aliphatic fraction and $300^{\circ} \mathrm{C}$ for aromatic fraction for $30 \mathrm{~min}$ and rate was $4{ }^{\circ} \mathrm{C} / \mathrm{min}$ for both aliphatic and aromatic fractions. Quantification of peaks and identification of hydrocarbons were done by a Perkin-Elmer computing integrator model LC-100. The Unresolved Complex Mixture (UCM) was measured using planimetry. The Odd and Even n-alkane Predominance Index (OEPI) and the Carbon Preference Indices (CPI) were used to indicate the general source of hydrocarbons whether their origin was biogenic or anthropogenic (API, 2001; Askari and Pollard, 2005). Pristane/Phytane ratio, Pristane $/ \mathrm{C}_{17}$ and Phytane $/ \mathrm{C}_{18}$ and the Unresolved
Complex Mixture index (UCM) were used as indicators of petroleum contamination (API, 2001; Barakat et al., 2001) and to estimate the degree of bacterial degradation (XiaoPing et al., 2007).

\section{RESULTS AND DISCUSSION}

The concentrations of total hydrocarbons in $\mu \mathrm{g} / \mathrm{g}$ and poly-nuclear aromatic hydrocarbons in $\mathrm{ng} / \mathrm{g}$ in the Basra soil samples are exhibited in Fig. 1 and $\mathbf{2}$ and listed in Table 1. The results of the preset work have clearly indicated that there is a significant differences in total hydrocarbon concentrations among industrial sites as oppose urban areas. As expected the rather elevated concentrations are always encountered in the industrial sites. An exception to this is Al-Seba site, where low levels of hydrocarbons were found despite the fact that Abadan Refinery lies across the river. The average concentrations of the total hydrocarbons in the urban sites were usually low, except in Al-Shiabah that shows relatively high concentrations mainly due to the impact of the oil refiner in Al-Rumella. However, the highest total hydrocarbons concentration was $38.8 \mu \mathrm{g} \mathrm{g}^{-1}$ found in AlRumayllah station where the lowest concentration was $13.0 \mu \mathrm{g} \mathrm{g}^{-1}$ found in Karmatt Ali station. Most of the soil samples collected during the study period showed emission peaks in the range of $340-380 \mathrm{~nm}$, which indicate presence of highly condensed aromatic ring that typically found in crude oil. Generally, the results show that the total hydrocarbons concentrations were higher in winter than that recorded for summer. This may be attributed mainly to temperature drop in winter and thus reduce hydrocarbon evaporation rate (Hamme et al., 2003; Wang and Fingas, 2003); however, these variation were not statistically insignificant $(p>0.005)$. Among the measured polynuclear aromatic hydrocarbons, benzo (a) pyrene was represented in high concentrations in the urban sites, while both benzo (a) pyrene and chrysene were found in high concentrations in the industrial sites (Fig. 2). The chromatographic distributions of carbon chain lengths of the average $n$-alkanes concentrations indicate different variations of peaks among the studied locations; however, these peaks exhibit a significant n-alkanes profile consisting of a uni-model distribution centered at $\mathrm{C}_{21}-\mathrm{C}_{26}$ (Fig. 3). The distribution of total average n-alkanes concentrations in the urban stations ranged from $9.2 \mu \mathrm{g} \mathrm{g}^{-1}$ $(+\mathrm{SE} 1.3)$ in Garmat Ali to $15.7 \mu \mathrm{g} \mathrm{g}^{-1}(+\mathrm{SE}$ 1.2) in Um Qasir, while their total average in the industrial locations ranged from $12.4 \mu \mathrm{g} \mathrm{g}^{-1}$ ( ${ }_{\mathrm{SSE}} 0.5$ ) in Al-Seba to $42.9 \mu \mathrm{g}$ $\mathrm{g}^{-1}( \pm \mathrm{SE} 5.7)$ in Al-Rumella (Table 2). 


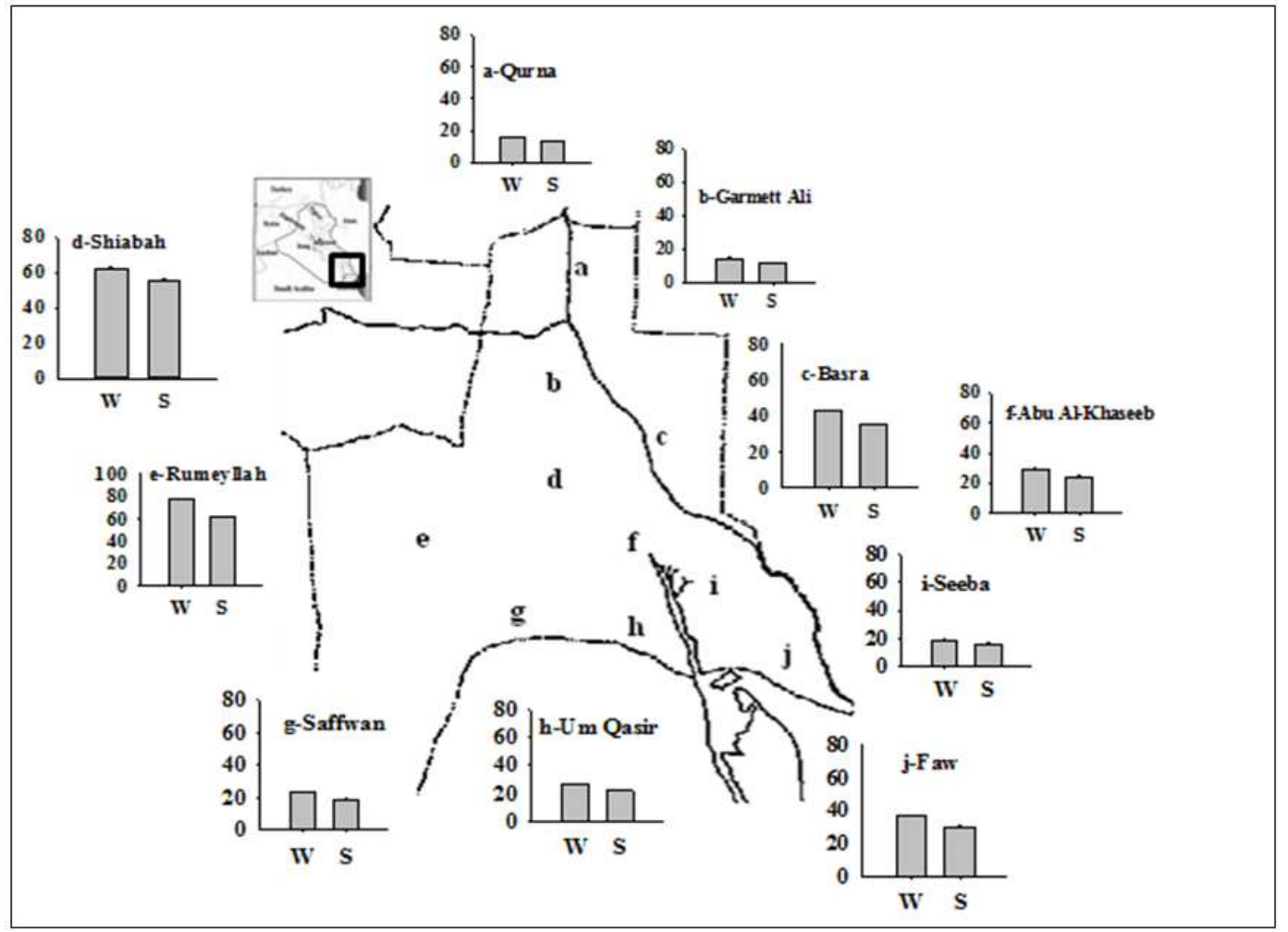

Fig. 1. Average concentrations of total hydrocarbons $(\mu \mathrm{g} / \mathrm{g} \pm \mathrm{SD})$ at the selected station in Basra governorate during winter and summer 2009

Table 1. Total hydrocarbons concentrations $(\mu \mathrm{g} / \mathrm{g} \pm \mathrm{SD}, \mathrm{W}=$ Winter, $\mathrm{S}=$ Summer) and poly-nuclear aromatic hydrocarbons (ng/g $\pm \mathrm{SD})$ among the sampling locations in Basra city during winter and summer 2009

\begin{tabular}{|c|c|c|c|c|c|c|c|c|}
\hline & $\begin{array}{l}\text { Total } \\
\text { Hydrocarbons-W }\end{array}$ & $\begin{array}{l}\text { Total } \\
\text { Hydrocarbons-S }\end{array}$ & Benzene & Naphthalene & Phenanthrene & Chrysene & $\begin{array}{l}\text { Benzo (a) } \\
\text { pyrene }\end{array}$ & $\begin{array}{l}(\mathrm{g}, \mathrm{h}, \mathrm{I}) \text { perylene } \\
\text { Benzo }\end{array}$ \\
\hline Al-Qurna & $15.7( \pm 0.5)$ & $12.9( \pm 0.3)$ & $0.5( \pm 0.1)$ & $1.0( \pm 0.7)$ & $0.3( \pm 0.0)$ & $0.3( \pm 0.1)$ & $0.5( \pm 0.2)$ & $0.4( \pm 0.2)$ \\
\hline Garmat Ali & $14.2( \pm 0.5)$ & $11.7( \pm 0.5)$ & $0.3( \pm 0.5)$ & $0.5( \pm 0.5)$ & $0.2( \pm 0.5)$ & $0.4( \pm 0.5)$ & $0.4( \pm 0.5)$ & $0.4( \pm 0.5)$ \\
\hline Center of Basrah & $42.6( \pm 0.3)$ & $35.0( \pm 0.2)$ & $1.3( \pm 0.1)$ & $1.7( \pm 0.3)$ & $1.7( \pm 0.4)$ & $1.2( \pm 0.0)$ & $1.6( \pm 0.5)$ & $1.2( \pm 0.0)$ \\
\hline Al-Shiabah & $62.4(+0.5)$ & $55.3( \pm 0.5)$ & $2.2( \pm 0.2)$ & $2.5( \pm 0.0)$ & $3.0( \pm 0.6)$ & $3.3( \pm 1.0)$ & $2.2( \pm 0.5)$ & $2.0( \pm 0.4)$ \\
\hline Al-Rumella & $77.4( \pm 0.1)$ & $61.6( \pm 0.7)$ & $2.5( \pm 0.1)$ & $3.1( \pm 0.8)$ & $3.3( \pm 0.5)$ & $4.3( \pm 0.3)$ & $2.7( \pm 0.1)$ & $2.8( \pm 0.5)$ \\
\hline Abu Al-Khasib & $29.2( \pm 0.6)$ & $24.2( \pm 0.5)$ & $1.0( \pm 0.4)$ & $1.5( \pm 0.2)$ & $1.3( \pm 0.5)$ & $1.1(+0.4)$ & $1.2( \pm 0.6)$ & $0.8( \pm 0.5)$ \\
\hline Al-Seeba & $18.7( \pm 0.4)$ & $16.0( \pm 0.1)$ & $0.9( \pm 0.4)$ & $0.5( \pm 0.1)$ & $0.5( \pm 0.1)$ & $0.4( \pm 0.1)$ & $07( \pm 0.2)$ & $0.4( \pm 0.1)$ \\
\hline Saffwan & $22.8( \pm 0.6)$ & $18.8( \pm 0.4)$ & $0.3( \pm 0.2)$ & $0.8( \pm 0.2)$ & $1.1( \pm 0.0)$ & $1.2( \pm 0.2)$ & $1.2( \pm 0.5)$ & $0.8( \pm 0.2)$ \\
\hline Um Qasir & $26.2( \pm 0.1)$ & $21.6( \pm 0.4)$ & $0.5( \pm 0.4)$ & $0.9( \pm 0.1)$ & $1.3( \pm 0.2)$ & $1.0( \pm 0.8)$ & $1.4( \pm 0.4)$ & $0.7( \pm 0.5)$ \\
\hline Al-Fao & $37.2( \pm 0.2)$ & $30.4( \pm 0.5)$ & $1.4( \pm 0.4)$ & $1.6( \pm 0.4)$ & $1.1( \pm 0.1)$ & $1.2( \pm 0.1)$ & $1.3( \pm 0.1)$ & $1.3( \pm 0.3)$ \\
\hline
\end{tabular}

The total average odd-even carbon numbers of nalkanes, CPI values, Pristane/Phytane ratio, Pristine $/ \mathrm{C}_{17}$ ratio, Phytane $/ \mathrm{C}_{18}$ ratio and $\mathrm{UCM}$ values in soil of the urban and industrial stations are listed in Table 3. In general, the calculated Indies indicate that hydrocarbons sources in the urban stations are mostly biogenic origins which are mainly organic matter originating from land plants (Barakat et al., 2001) or resulted due to microbial activity (Wang and Fingas,
2003), except in Al-Shiabah and Al-Qurna stations, where the hydrocarbons sources were mainly anthropogenic origins. The anthropogenic sources in Al-Qurna station is mainly contributed to the high urban activities, while in Al-Shiabah station can be related to the impact of the oil refiner in Al-Rumella. The high UCM values represented in all soil samples during the study period indicate recent hydrocarbons contamination, which mainly petroleum. 


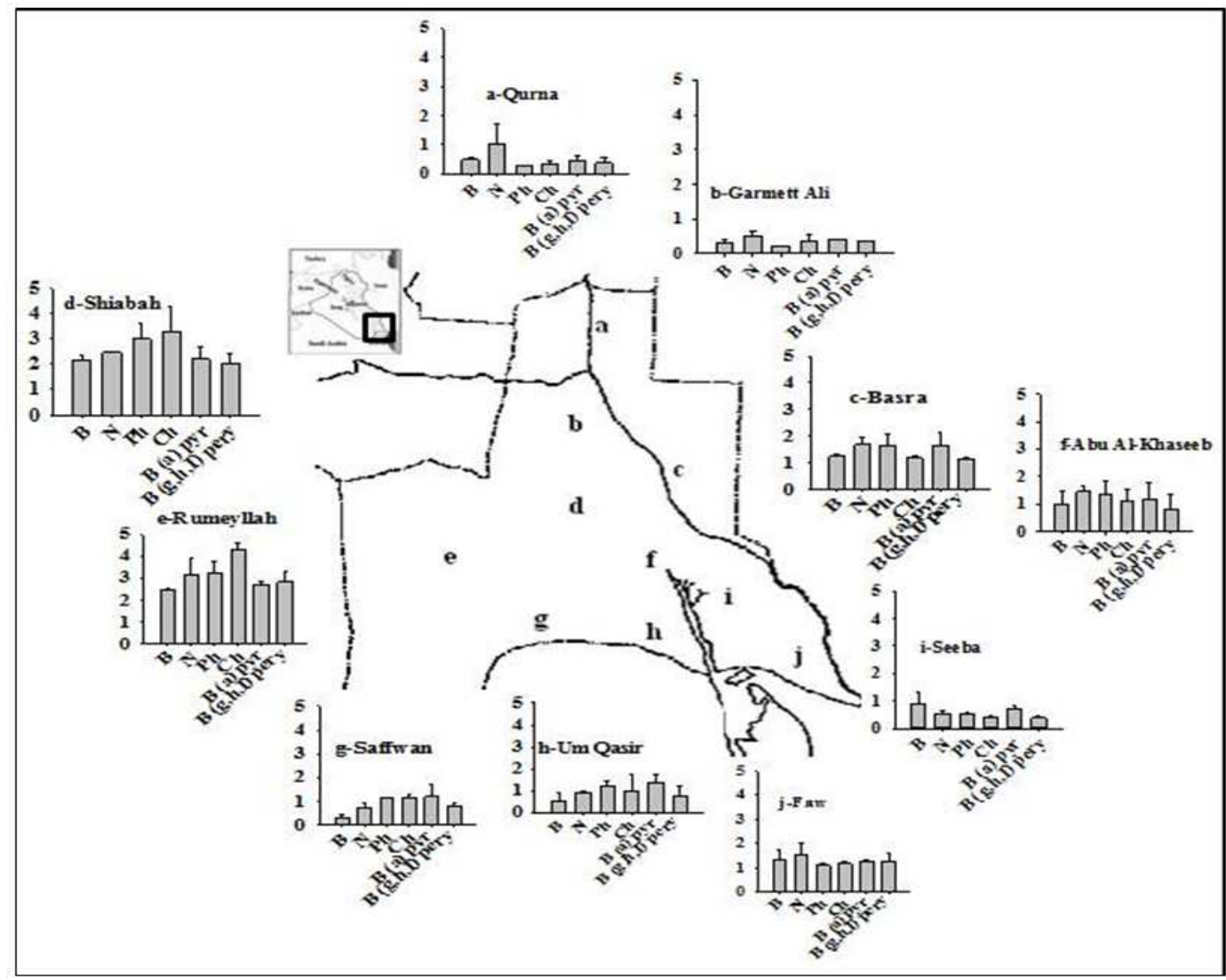

Fig. 2. Average concentrations of polynuclear hydrocarbons (ng/g $\pm \mathrm{SD} ; \mathrm{B}=$ benzene, $\mathrm{N}=$ naphthalene, $\mathrm{Ph}=$ phenanthrene, $\mathrm{Ch}=$ chrysene, B (a) pyr = benzo (a) pyrene, B $(\mathrm{g}, \mathrm{h}, \mathrm{i})=$ benzo $(\mathrm{g}, \mathrm{h}, \mathrm{i})$ perylene) at the selected station in Basra governorate during winter and summer 2009

Table 2. Mean n-alkanes concentrations $(\mu \mathrm{g} / \mathrm{g})$ and standard error in the soil samples of the selected stations in Basra governorate during the study period

\begin{tabular}{|c|c|c|c|c|c|c|c|c|c|c|c|c|c|c|c|c|c|c|c|c|}
\hline $\begin{array}{l}\text { Carbon } \\
\text { Chain }\end{array}$ & $\begin{array}{l}\text { Al- } \\
\text { Qurna }\end{array}$ & SE & $\begin{array}{l}\text { Garma } \\
\text { ali }\end{array}$ & SE & $\begin{array}{l}\text { Center } \\
\text { of basra }\end{array}$ & SE & $\begin{array}{l}\text { Al- } \\
\text { Shiabah }\end{array}$ & SE & $\begin{array}{l}\text { Al- } \\
\text { Rumella }\end{array}$ & SE & $\begin{array}{l}\text { Abu Al- } \\
\text { Khasib }\end{array}$ & SE & $\begin{array}{l}\text { Al- } \\
\text { Seba }\end{array}$ & SE & Saffwan & SE & $\begin{array}{l}\text { Um } \\
\text { Qasir }\end{array}$ & SE & $\begin{array}{l}\text { Al- } \\
\text { Fao }\end{array}$ & SE \\
\hline$\overline{C_{12}}$ & 0.31 & 0.3 & 0.15 & 0.1 & 0.55 & 0.5 & 1.77 & 0.3 & 2.49 & 1.0 & 0.21 & 0.2 & 0.20 & 0.2 & 0.31 & 0.3 & 0.32 & 0.3 & 0.36 & 0.3 \\
\hline $\mathrm{C}_{13}$ & 0.29 & 0.2 & 0.25 & 0.2 & 0.48 & 0.3 & 1.63 & 1.0 & 1.87 & 0.1 & 0.46 & 0.1 & 0.18 & 0.2 & 0.32 & 0.3 & 0.61 & 0.4 & 0.48 & 0.7 \\
\hline $\mathrm{C}_{14}$ & 0.73 & 0.7 & 0.31 & 0.3 & 0.92 & 0.2 & 1.98 & 0.8 & 1.47 & 0.6 & 0.71 & 0.3 & 0.17 & 0.1 & 0.63 & 0.7 & 0.51 & 0.3 & 0.44 & 0.5 \\
\hline $\mathrm{C}_{15}$ & 0.35 & 0.4 & 0.35 & 0.2 & 0.84 & 0.8 & 1.43 & 0.9 & 2.32 & 0.3 & 0.26 & 0.1 & 0.21 & 0.1 & 0.36 & 0.2 & 0.62 & 0.4 & 0.32 & 0.3 \\
\hline $\mathrm{C}_{16}$ & 0.38 & 0.3 & 0.06 & 0.0 & 0.42 & 0.9 & 1.89 & 1.1 & 1.54 & 1.5 & 0.40 & 0.2 & 0.38 & 0.1 & 0.56 & 0.3 & 0.57 & 0.5 & 0.40 & 0.3 \\
\hline $\mathrm{C}_{17}$ & 0.44 & 0.3 & 0.25 & 0.2 & 1.59 & 0.4 & 1.93 & 1.5 & 2.32 & 1.3 & 0.98 & 0.3 & 0.73 & 0.2 & 0.53 & 0.5 & 0.64 & 0.6 & 0.99 & 0.3 \\
\hline $\mathrm{C}_{18}$ & 0.56 & 0.3 & 0.24 & 0.2 & 1.48 & 0.6 & 1.99 & 1.8 & 2.81 & 1.8 & 0.50 & 0.1 & 0.63 & 0.1 & 0.62 & 0.5 & 0.78 & 0.7 & 0.96 & 0.3 \\
\hline $\mathrm{C}_{19}$ & 0.57 & 0.5 & 0.21 & 0.4 & 1.59 & 1.0 & 1.93 & 1.8 & 2.70 & 1.8 & 0.38 & 0.3 & 0.58 & 0.3 & 0.30 & 0.6 & 0.63 & 0.4 & 1.28 & 0.5 \\
\hline $\mathrm{C}_{20}$ & 0.52 & 0.5 & 0.59 & 0.2 & 1.78 & 1.5 & 1.08 & 2.4 & 2.30 & 2.3 & 0.57 & 0.5 & 0.77 & 0.4 & 0.78 & 0.6 & 0.85 & 0.8 & 0.88 & 0.5 \\
\hline $\mathrm{C}_{21}$ & 0.65 & 0.6 & 0.56 & 0.4 & 1.53 & 1.9 & 2.85 & 2.6 & 2.26 & 2.0 & 1.32 & 1.6 & 0.32 & 1.0 & 0.54 & 0.5 & 0.86 & 0.8 & 0.87 & 0.9 \\
\hline $\mathrm{C}_{22}$ & 0.45 & 0.5 & 0.70 & 0.4 & 1.54 & 1.4 & 1.61 & 2.6 & 2.32 & 1.3 & 0.66 & 0.6 & 0.35 & 0.7 & 0.72 & 0.7 & 1.55 & 1.0 & 1.38 & 1.2 \\
\hline $\mathrm{C}_{23}$ & 0.88 & 0.7 & 0.91 & 0.7 & 1.63 & 1.0 & 1.85 & 1.6 & 2.30 & 2.1 & 1.38 & 1.3 & 0.63 & 0.8 & 0.89 & 0.9 & 0.96 & 0.9 & 1.06 & 1.1 \\
\hline $\mathrm{C}_{24}$ & 0.78 & 0.7 & 0.84 & 0.5 & 2.06 & 1.3 & 2.96 & 2.1 & 2.74 & 2.3 & 0.40 & 0.4 & 1.24 & 0.5 & 0.93 & 0.9 & 0.58 & 0.9 & 1.22 & 1.2 \\
\hline $\mathrm{C}_{25}$ & 0.54 & 0.5 & 0.73 & 0.6 & 1.63 & 1.5 & 1.80 & 1.6 & 2.68 & 2.1 & 0.45 & 1.4 & 0.56 & 0.4 & 0.88 & 0.8 & 0.86 & 0.8 & 1.46 & 1.0 \\
\hline $\mathrm{C}_{26}$ & 0.63 & 0.7 & 0.56 & 0.5 & 1.92 & 1.9 & 1.92 & 1.9 & 2.86 & 1.1 & 1.36 & 1.0 & 1.64 & 0.9 & 0.69 & 0.6 & 1.63 & 0.6 & 1.91 & 1.8 \\
\hline $\mathrm{C}_{27}$ & 0.33 & 0.2 & 0.63 & 0.6 & 1.58 & 1.8 & 1.80 & 1.6 & 2.77 & 2.5 & 0.34 & 0.4 & 1.20 & 0.5 & 0.65 & 0.6 & 0.77 & 0.8 & 1.02 & 0.7 \\
\hline $\mathrm{C}_{28}$ & 0.39 & 0.3 & 0.67 & 0.5 & 1.52 & 1.6 & 1.98 & 1.9 & 2.68 & 2.4 & 1.21 & 0.4 & 1.10 & 1.6 & 0.49 & 0.5 & 0.53 & 0.9 & 1.33 & 1.3 \\
\hline $\mathrm{C}_{29}$ & 0.34 & 0.3 & 0.42 & 0.3 & 1.78 & 1.6 & 1.69 & 1.7 & 2.57 & 2.4 & 0.35 & 1.2 & 1.09 & 0.8 & 0.94 & 0.7 & 0.63 & 0.8 & 1.16 & 1.7 \\
\hline $\mathrm{C}_{30}$ & 0.29 & 0.3 & 0.50 & 0.5 & 1.89 & 1.6 & 1.86 & 1.5 & 1.22 & 1.9 & 1.18 & 0.5 & 0.32 & 1.0 & 0.91 & 0.7 & 0.93 & 0.9 & 1.15 & 1.6 \\
\hline $\mathrm{C}_{31}$ & 0.22 & 0.2 & 0.67 & 0.6 & 1.43 & 1.7 & 1.63 & 1.8 & 1.31 & 2.3 & 0.15 & 0.4 & 0.16 & 1.6 & 0.88 & 0.4 & 0.84 & 0.7 & 0.49 & 1.6 \\
\hline$C_{32}$ & 0.19 & 0.2 & 0.59 & 0.3 & 0.48 & 0.9 & 1.46 & 1.9 & 1.12 & 1.8 & 0.10 & 0.1 & 0.16 & 0.3 & 0.65 & 0.3 & 0.64 & 0.5 & 0.53 & 0.7 \\
\hline $\mathrm{C}_{33}$ & 0.12 & 0.1 & 0.15 & 0.1 & 0.28 & 0.2 & 0.46 & 0.6 & 0.16 & 1.1 & 0.08 & 0.1 & 0.10 & 0.2 & 0.15 & 0.2 & 0.20 & 0.2 & 0.23 & 0.2 \\
\hline$C_{34}$ & 0.11 & 0.1 & 0.09 & 0.1 & 0.25 & 0.2 & 0.34 & 0.3 & 1.10 & 1.1 & 0.11 & 0.1 & 0.08 & 0.0 & 0.18 & 0.1 & 0.16 & 0.2 & 0.16 & 0.1 \\
\hline $\mathrm{C}_{35}$ & 0.11 & 0.1 & 0.08 & 0.1 & 0.19 & 0.2 & 0.27 & 0.3 & 0.79 & 0.2 & 0.11 & 0.1 & 0.09 & 0.0 & 0.16 & 0.1 & 0.19 & 0.2 & 0.12 & 0.2 \\
\hline
\end{tabular}




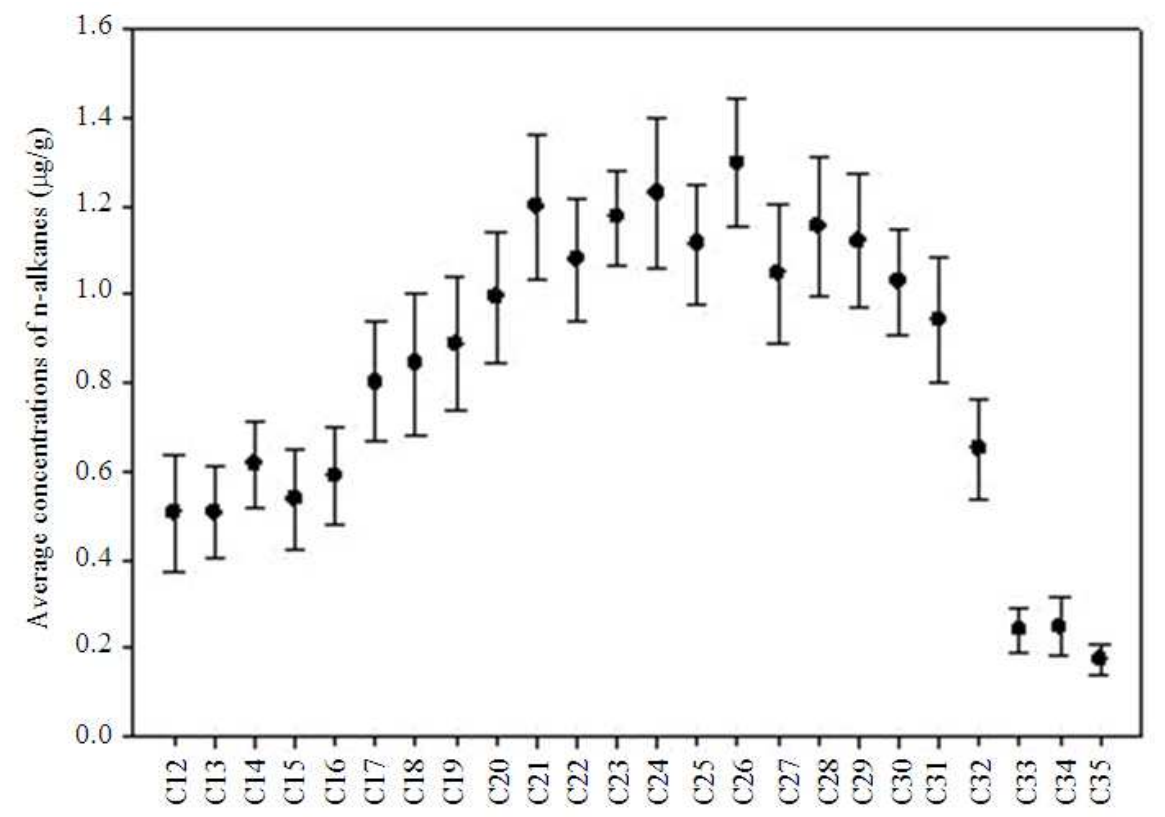

Carbons chain

Fig. 3. Chromatographic distributions of carbon chain lengths of the average $n$-alkanes concentrations $(\mu \mathrm{g} / \mathrm{g} \pm \mathrm{SE})$ from the sampled locations in Basra governorate during winter and summer 2009

Table 3. Odd/Even n-alkanes values, CPI values, Pristane/Phytane ratio, Pristane/ $\mathrm{C}_{17}$ ratio, Phytane $/ \mathrm{C}_{18}$ ratio and UCM values in the soil samples of the selected stations in Basra governorate during the study period

\begin{tabular}{|c|c|c|c|c|c|c|c|c|c|c|c|c|c|c|c|c|c|c|c|c|}
\hline & \multicolumn{2}{|c|}{$\begin{array}{l}\text { Al- } \\
\text { Qurna }\end{array}$} & \multicolumn{2}{|c|}{$\begin{array}{l}\text { Garmat } \\
\text { ali }\end{array}$} & \multicolumn{2}{|c|}{$\begin{array}{l}\text { Center } \\
\text { of }\end{array}$} & \multicolumn{2}{|c|}{$\begin{array}{l}\text { Al- } \\
\text { Rumella }\end{array}$} & \multicolumn{2}{|c|}{$\begin{array}{l}\text { Al- } \\
\text { Shiabah }\end{array}$} & \multicolumn{2}{|c|}{$\begin{array}{l}\text { Abu Al- } \\
\text { Khasib }\end{array}$} & \multicolumn{2}{|c|}{$\begin{array}{l}\text { Al- } \\
\text { Seba }\end{array}$} & \multicolumn{2}{|c|}{ Saffwan } & \multicolumn{2}{|c|}{$\begin{array}{l}\text { Um } \\
\text { Qasir }\end{array}$} & \multicolumn{2}{|c|}{ Al-Fao } \\
\hline & W & $\mathrm{S}$ & W & $\mathrm{S}$ & W & $\mathrm{S}$ & W & $\mathrm{S}$ & W & $\mathrm{S}$ & W & $\mathrm{S}$ & W & $\mathrm{S}$ & W & $\mathrm{S}$ & W & $\mathrm{S}$ & W & $\mathrm{S}$ \\
\hline $\begin{array}{l}\text { Odd/Even } \\
\text { n-alkane }\end{array}$ & 0.9 & 0.9 & 1.0 & 1.2 & 1.0 & 1.0 & 0.9 & 0.9 & 1.0 & 0.9 & 0.8 & 1.7 & 1.0 & 1.0 & 0.9 & 1.0 & 0.9 & 0.9 & 0.9 & 0.9 \\
\hline CPI & & 0.9 & & 1.2 & 1.0 & 1.0 & & 0.9 & 1.0 & 0.9 & 1.9 & 1.7 & & 1.1 & & 1.0 & & 0.9 & & 0.9 \\
\hline $\begin{array}{l}\text { Pristane/ } \\
\text { Phytane }\end{array}$ & 0.9 & 0.9 & 1.1 & 1.2 & 1.0 & 0.9 & 0.9 & 0.9 & 0.9 & 0.9 & 2 & 1.8 & 1.3 & 1.5 & 0.9 & 1.0 & 0.9 & 0.9 & 0.9 & 0.9 \\
\hline Prista & & 1. & & 0.9 & 1. & 1.0 & 1. & 1. & 1. & 1. & 1 & 0.9 & 0. & 0. & & 1.3 & & & & 1.1 \\
\hline Phytane & 1.1 & 1.1 & & 0.9 & 1.0 & 1.3 & 1. & 1.2 & 1.1 & 1.2 & 1 & 0.8 & 0.9 & 0.8 & 1.1 & 1.1 & & 1.4 & D. & 1.1 \\
\hline UCM & 7.0 & 5.8 & 3.3 & 2.1 & 9.0 & 7.6 & 9.5 & 7.5 & 11.4 & 9.5 & 2.5 & 2.4 & 3.2 & 3.0 & 7.0 & 6.9 & 8.3 & 7.3 & 8.5 & 7.0 \\
\hline
\end{tabular}

\section{CONCLUSION}

The survey determined the background information of total hydrocarbons concentrations in the soil and their distribution in the industrial zone and their surrounded urbanization in Basra Governorate. The present data may be used in future environmental impact assessment studies. The refined oils and gas production plants, electrical generating stations, oil wastes discharges, transportation and domestic activities could be the possible sources of anthropogenic hydrocarbons in the sampled locations. Similar findings were reported by several authors for example (Li et al., 2006; 2010;
Mielke et al., 2001). On the other hand seeps from oil deposits, degradation of organic matter and synthesis by certain organisms might represent the natural sources Meharg et al. (1998). Part of the urban locations areas are subject to contaminated by petroleum hydrocarbons (Sojinu et al., 2010). Every possible effort should be made to minimize petroleum plants wastes by applying outfall licenses to specify permissible levels on the basis of the most toxic fractions of petroleum released into the environment. In addition, aromatic hydrocarbons should be carefully monitored in the soil in order to provide their minimum and acceptable levels within the industrial and urbanization areas to human, fauna and flora. 


\section{ACKNOWLEDGEMENT}

The reacheres wish to acknowledge the Marine Science Center, University of Basra for providing the laboratory facilities.

\section{REFERENCES}

API, 2001. Risk-based methodologies for evaluating petroleum hydrocarbon impacts at oil and natural gas E\&P Sites. American Petroleum Institute.

Apitz, S.E. and K.J. Meyers-Schulte, 1996. Effects of substrate mineralogy on the biodegradability of fuel components. Environ. Toxicol. Chem., 15: 18831893. DOI: $10.1002 /$ etc.5620151105

Askari, K. and S. Pollard, 2005. The UK Approach for Evaluating Human Health Risks from Petroleum Hydrocarbons in Soils. 1st Edn., Environment Agency, Bristol, ISBN-10: 1844323420,pp: 22.

Barakat, A.O., Qian Y., Kim M. and Kennicutt M.C., 2001. Chemical characterization of naturally weathered oil residues in arid terrestrial environment in Al-Alamein, Egypt. Environ. Int., 27: 291-310. PMID: 11686640

Buddhadasa, S.C., S. Barone, S.W. Bigger and J.D. Orbell, 2002. Australian approaches to improving methods for the analysis of TPH contamination in soil. Proceedings of the 17th World Congress of Soil Science, Aug. 14-21, Bangkok, Thailand.

Butler, J.D., V. Butterworth, S.C. Kellow and H.G. Robinson, 1984. Some observations on the Polycyclic Aromatic Hydrocarbon (PAH) content of surface soils in urban areas. Sci. Total Environ., 33: 75-85. DOI: 10.1016/0048-9697(84)90382-6

Farrell-Jones, J., 2003. Petroleum Hydrocarbons and Polyaromatic Hydrocarbons. In: Chemical Analysis of Contaminated Land, Thompson, C.K. and P.C. Nathanail (Eds.)., Blackwell, Oxford ISBN-10: 0849328101.

Grimalt, J.O. and J. Olive, 1993. Source input elucidation in aquatic systems by factor and principal component analysis of molecular marker data. Anal. Chim. Acta, 278: 159-176. DOI: 10.1016/0003-2670(93)80094-2

Hamme, J.D.V., A. Singh and O.P. Ward, 2003. Recent advances in petroleum microbiology. Microbiol. Mol. Biol. Rev., 67: 503-549. DOI: 10.1128/MMBR.67.4.503-549.2003
Li, X., S. Tao, W. Liu, X. Li and H. Chen et al., 2010. Dry deposition of polycyclic aromatic hydrocarbons and its influence on surface soil contamination in Tianjin, China. J. Environ. Monitor., 12: 952-957. DOI: $10.1039 / \mathrm{B} 919054 \mathrm{~F}$

Li, X.H., L.L. Ma, X.F. Liu, S. Fu and H.X. Cheng et al., 2006. Polycyclic aromatic hydrocarbon in urban soil from Beijing, China. J. Environ. Sci., 18: 944-950. DOI: $10.1016 / \mathrm{S} 1001-0742(06) 60019-3$

Meharg, A.A., J. Wright, H. Dyke and D. Osborn, 1998. Polycyclic Aromatic Hydrocarbon (PAH) dispersion and deposition to vegetation and soil following a large scale chemical fire. Environ. Pollut., 99: 2936. DOI: 10.1016/S0269-7491(97)00180-2

Mielke, H.W., G. Wang, C.R. Gonzales, B. Le and V.N. Quach et al., 2001. PAH and metal mixtures in New Orleans soils and sediments. Sci. Total Environ., 281: 217-227. DOI: 10.1016/S0048-9697(01)00848-8

Sojinu, S.O.S., J.W. Wang, S.O.O. Eddy and Y. Zenga, 2010. Polycyclic aromatic hydrocarbons in sediments and soils from oil exploration areas of the Niger Delta, Nigeria. J. Hazard. Mater., 174: 641647. DOI: 10.1016/j.jhazmat.2009.09.099

Tuteja, G., C. Rout and N.R. Bishhnoi, 2011. Quantification of polycyclic aromatic hydrocarbons in leafy and underground vegetables: A case study around Panipat City, Haryana, India. J. Environ. Sci. Technol., 4: 611-620.

Wang, Z. and M. Fingas, 2003. Fate and identification of spilled oils and petroleum products in the environment by GC-MS and GC-FID. Energy Sources, 25: 491-508. DOI: 10.1080/00908310390195570

Whittaker, M., S.J. Pollard and G. Risden, 1999. The fate of heavy oil wastes in soil microcosms. II: A performance assessment of source correlation indices. Sci. Total Environ., 226: 23-34. PMID: 10077872

XiaoPing, W., Y. TanDong, C. ZhiYuan, Y. XinLiang and K. ShiChang et al., 2007. Concentration level and distribution of polycyclic aromatic hydrocarbons in soil and grass around Mt. Qomolangma, China. Chinese Sci. Bull., 52: 1405-1413.

Zhang, J., R. Wang, X. Du, F. Li and J. Dai, 2012. Characterization of contamination, source and degradation of petroleum between upland and paddy fields based on geochemical characteristics and phospholipid fatty acids. 